\title{
Enforcement Actions, Market Movement and Depositors' Reaction: Evidence from the US Banking System
}

\author{
John Pereira ${ }^{1} \cdot$ Irma Malafronte $^{2} \cdot$ Ghulam Sorwar $^{3} \cdot$ Mohamed Nurullah $^{1}$ \\ Received: 29 August 2016 / Revised: 18 June 2018 / Accepted: 6 March 2019 / \\ Published online: 13 April 2019 \\ (C) Springer Science+Business Media, LLC, part of Springer Nature 2019
}

\begin{abstract}
We examine market movement and depositors' reaction following the announcement of enforcement actions (EAs) on US banks over the period 2004 to 2015. Using an extensive dataset of manually collected EAs, employing event study and multivariate analyses, we investigate the impact of EAs on key bank stakeholders, i.e. shareholders and depositors. Our findings suggest that equity market and depositors are able to discriminate EAs based on their severity. Market reacts negatively following severe EAs (cease and desist) while weak reaction is noted for other EA types (civil money penalty and formal agreements). Demand depositors exhibit some level of depositor disciplining mechanism following cease and desist announcements, while core depositors seem to reward sanctioned banks for a higher return. A positive effect is found following formal agreement announcements that seem to be perceived as a corrective mechanism. We validate these findings across the sanctioned (treatment) and comparable non-sanctioned (control) banks, using propensity score matching methodology. These findings have important policy implications and expand the existing knowledge on the consequences of banking supervision to guide banks' behaviour, drive policy interventions and contribute to enhance supervisory effectiveness.
\end{abstract}

Keywords Enforcement actions · Event study $\cdot$ Propensity score $\cdot$ Depositors

JEL Classification $\mathrm{G} 14 \cdot \mathrm{G} 21 \cdot \mathrm{G} 28$

\section{Introduction}

One of the major purposes of bank regulation is to ensure institutions maintain safe and sound business practices, by conducting supervision and, in particular, bank safety and soundness examinations (Curry et al. 1999). Enforcement actions (hereinafter referred to as EAs) are an

John Pereira

J.Pereira@kingston.ac.uk

Extended author information available on the last page of the article 
essential part of the supervisory mechanism that ensure actual operations are consistent with sound practises and represent the most vital component of effective banking supervision (Delis et al. 2013). When unsafe or illegal activities are identified, regulators have the power to enforce sanctions by imposing appropriate corrective actions, compelling safe practises as well as inducing an alteration in banks' behaviour, thereby averting future potential losses and ensuring stability and soundness. In the execution of their supervisory activities, banking regulators can take a variety of formal or informal EAs ${ }^{1}$ against financial institutions and their affiliated parties in case of violations of laws, rules or regulations, unsafe or unsound practices, breaches of fiduciary duty and violations of final orders. ${ }^{2}$

EAs could be idiosyncratic in nature as well as reflect market conditions and/or supervisory focus at a specific point in time (Srinivas et al. 2015). Moreover, as formal EAs are publicly available, sanctioned institutions experience both direct (i.e. financial penalty, actions to correct the problem identified) and indirect costs (i.e. reputational loss, panic among investors).

Banking supervisory actions aim to prevent the occurrence of systemic risk in the banking sector as well as to increase transparency and contribute to the protection of small depositors (Davis and Obasi 2009). However, following the financial crisis, there is a growing need for a fresh reconsideration in the approach of banking supervision and the effectiveness of the corrective actions, in the interest of banks themselves and their stakeholders.

Previous studies have investigated the impact of EAs on bank capital, risk and performance (i.e. Curry et al. 1999; Delis and Staikouras 2011; Chortareas et al. 2012; Delis et al. 2013; Filotto et al. 2014) and found conflicting evidence. Recent studies also focus on the effect of EAs on the real economy (Danisewicz et al. 2014) and corporate culture (Cerqueti et al. 2016). However, there is limited literature that investigates how financial markets react to supervisory actions (i.e. Brous and Leggett 1996; Jordan et al. 1999; Zeidan 2013; Ren 2015) and depositors' disciplining mechanism (i.e. Gilbert and Vaughan 2001; Semenova 2007). To the best of our knowledge, there is no thorough investigation of how key bank stakeholders, i.e. shareholders and depositors, react to US banks EAs.

Investigating whether and how equity market and depositors respond to the announcement of EAs in the banking sector is a relevant issue due to the crucial role of banks in the financial system. Indeed, the banking industry is heavily regulated, in the interest of depositors as well as to safeguard integrity and the reputation of the financial system (Zeidan 2013). By compelling banks to implement corrective actions, adopt safe practices, incur civil money penalties, among others, EAs have the potential to affect banks' operations, profitability, and valuation, and can be seen as an indicator of unsafe or unsound operations. Therefore, apart from being a supervisory discipline mechanism issued to sanction bank misconduct, EAs represent a wider action involving customer protection, market integrity, safety, soundness, and corporate governance. On the one hand, EAs may lead to an overreaction by shareholders and investors, affecting share price and cost of capital (Zeidan 2013). Indeed, when deciding to purchase bank equity, investors assess that the bank is safe and sound, and that the investment

\footnotetext{
${ }^{1}$ Formal enforcement actions include, among others, cease and desist orders, written agreements, prompt corrective action directives, removal and prohibition orders and orders assessing civil money penalties. Informal enforcement actions include, among others, memorandum of understanding, board resolution, and commitment letter. Unlike informal enforcement actions, formal enforcements are publicly disclosed. In either case, the extent of action, either wilfully or through reckless conduct, depends on the magnitude and seriousness of violations from the prescribed banking practices.

${ }^{2}$ Source: Federal Reserve available at http://www.federalreserve.gov/apps/enforcementactions/. URL last accessed on 23 April 2018.
} 
yields the expected return (Bruno et al. 2016); EAs may therefore lead investors to revise their expected returns and their investment decisions on bank equity. On the other hand, depositors may be unwilling to bring money to a bank with uncertain liquidity and solvency (Semenova 2007); depositors may panic and can either withdraw funds or demand higher returns (Gilbert and Vaughan 2001). As a result, investors and depositors may be reluctant to provide funds to banks following EAs, and in the worst case scenario, this loss of investor and depositor confidence can lead to systemic repercussions that would require further intervention (Jordan et al. 1999; Gilbert and Vaughan 2001; Bruno et al. 2016).

Within this context, we investigate market movement and depositors' reactions following EA announcements in the US banking sector over the period 2004-2015. First, we build a unique dataset of EA announcements issued by US supervisory authorities. This sample of sanctioned banks is matched to a sample of comparable non-sanctioned banks by applying a propensity score matching (PSM) methodology. Second, we investigate the market reaction following the announcement of EAs, using event study methodology and testing for causality to answer the following question: How does the equity market react to the different types of EA announcements in the US banking system? Third, we investigate depositors' reaction to EAs to address the second research question: How do depositors react to the different types of EA announcements in the US banking system?

The main results show that equity market reacts negatively following cease and desist (C\&D) announcements, while weak or no reaction is found for other EA types, documenting the ability of equity market to discriminate EAs based on their severity. Moreover, a negative market reaction following C\&D announcements suggests that more severe EAs are not fully anticipated by the market. These findings are robust when comparing sanctioned banks with non-sanctioned ones. Depositors exhibit different behaviour depending on the type of sanction and the type of deposit considered. Demand depositors penalize sanctioned banks following C\&D announcements. However, a positive effect on depositors can be noted following FA announcements, suggesting depositors perceive FA to be a corrective mechanism. Robustness checks on both sanctioned and non-sanctioned banks further validate these results.

This research complements the existing literature on bank EAs, by providing new empirical evidence on the impact of EAs on key bank stakeholders, i.e. shareholders and depositors. We contribute to previous literature (i.e. Brous and Leggett 1996; Gilbert and Vaughan 2001; Zeidan 2013) by providing empirical evidence across a range of EA types (cease and desist, civil money penalty, formal agreements) and deposit types (saving, demand, time, core). To this aim, we use a more recent, manually collected and wider dataset on different types of sanctions enforced by Board of Governors of the Federal Reserve System (FED), Office of the Comptroller of the Currency (OCC), and Federal Deposit Insurance Corporation (FDIC) on US banks, thus enhancing the scope of investigation. We complement previous studies (i.e. Gilbert and Vaughan 2001; Zeidan 2013) by testing for causality of EA announcements on market and depositors' reaction, thus enhancing the reliability of the findings. Differently from previous studies, the analysis is carried out for both the sanctioned banks as well as comparable nonsanctioned banks identified using PSM methodology, thus further validating the causeeffect relationship. By providing an in-depth empirical analysis on the effect of supervisory actions on key bank stakeholders, this study provides a better understanding of how EAs are perceived by shareholders and depositors; this can guide banks' behaviour, drive future policy interventions and contribute to enhance supervisory effectiveness. 
The remainder of the paper is organized as follows. Section 2 reviews the existing literature and identifies the research hypotheses. Section 3 defines the sample selection process and the methodology. Section 4 discusses the empirical results and Section 5 concludes the paper.

\section{Literature}

The analysis on the effects of regulatory EAs on banking institutions is a wide research field. Most of the existing literature investigates the impact of EAs on banks' behaviour, specifically looking at capital, risk and performance (Section 2.1). Further literature focuses on previous studies related to market reaction (Section 2.2) and depositors' reaction (Section 2.3).

\subsection{The Effect of Enforcement Actions on Banks}

A substantial stream of literature investigates the effect of EAs on bank capital, risk and performance, and finds contrasting evidence. Peek and Rosengren (1995) examine supervisors' intervention when a bank's financial situation deteriorates and find formal regulatory actions that require higher bank capital ratios lead to reductions in bank lending. Further, few banks are able to raise new equity at a reasonable cost, while most banks need to decrease their assets (Peek and Rosengren 1996). Within this field, focusing on US financially distressed banks during 1980-1996, Curry et al. (1999) find that banks that received formal actions had more pronounced changes in their performance measures than the banks that experienced a downgrade in their CAMELS ${ }^{3}$ rating. Moreover, EAs are found to be more effective in correcting weaknesses that bank management can control (i.e. cash dividends, loan-loss provisions and loan charge-offs) than areas where management has limited control (i.e. external capital injections, asset growth).

From the risk perspective, Delis and Staikouras (2011) examine how banking supervision across 17 countries over the period 1998-2008 is able to control bank risk and find a non-linear relationship between on-site audits and bank risk, while a linear negative relationship exists between sanctions and risk. In a further paper, they extend this study to the impact of EAs on US banks' risk-based capital, risk and performance over the period 2000-2010 (Delis et al. 2013); following an EA, riskweighted capital falls, the risk-weighted asset ratio declines to levels approximately equal to the industry average, while profitability increases. Chortareas et al. (2012) analyse the relationship between bank supervision, regulation and efficiency for a sample of commercial banks operating in 22 EU countries from 2000 to 2008 . Their results show that strong capital restrictions and official supervisory powers can improve the efficient operation of banks, and these beneficial effects are more pronounced in countries with better quality institutions.

Focusing on the Italian banking system, Brogi (2011) shows that administrative sanctions issued by the Bank of Italy from 1998-2009 are not effective in disciplining board members or banks, recidivism is extremely widespread and sanctions do not prevent re-election of the same bank board members. Within the same context, Filotto et al. (2014) find that administrative sanctions issued by the Bank of Italy over 2005-2012 are not effective in improving bank risk profile and performance; in fact, banks receiving sanctions are riskier, less profitable, and less capitalized than non-sanctioned ones.

\footnotetext{
${ }^{3}$ CAMELS identifies the six areas that bank examiners review (also known as safety and soundness rating): Capital adequacy, Asset quality, Management, Earnings, Liquidity and Sensitivity to market risk (Curry et al. 1999).
} 
More recent research focuses on the effect of EAs on other factors including the real economy and corporate culture (Danisewicz et al. 2014; Cerqueti et al. 2016). Danisewicz et al. (2014) show that regulatory EAs on banks trigger significant adverse effects on the macro economy; in particular, severe actions like cease and desist orders imposed on single-market banks reduce personal income growth in US rural counties. Cerqueti et al. (2016) examine if supervisory actions influence bank culture using a sample of EAs on US banks for 2006-2013. Their results show that low regulatory capital ratios, low performance and high credit-risk indicators tend to attract EAs. Banks with high probability of being sanctioned tend to become more conservative and prudent along internal cultural dimensions and changes in culture appear unrelated to changes in bank activity and capital adequacy ratios.

However, none of the above studies investigates the impact of EAs on banks' stakeholders. To the best of our knowledge, there is limited research on the effects of EAs in particular on the equity market and depositors. Moreover, supervisors can enforce different types of sanctions depending on the magnitude and seriousness of violations from the prescribed banking practices; however, previous literature does not always make a clear distinction based on the type of EA. This study contributes to the existing literature by investigating how equity market and depositors react to the announcement of different types of EAs in the US banking sector.

\subsection{Enforcement Actions and Market Reaction}

The relationship between EAs and market reaction has been investigated by previous studies (Brous and Leggett 1996; Jordan et al. 1999; Zeidan 2013; Ren 2015). Seminal empirical evidence comes from Brous and Leggett (1996) that examine stock price reaction to EAs, including cease and desist orders and written agreements, for a sample of US commercial banks from 1989-1991. They find significant negative abnormal returns, suggesting EAs are not fully anticipated by the market and, on average, are perceived as unfavourable for bank shareholders. Similarly, Jordan et al. (1999) find the announcement of formal EAs to be informative for stock market participants, resulting in a large negative abnormal stock return for sanctioned banks. Moreover, improving disclosure requirements for troubled US banks during the banking crisis allowed market discipline to work more effectively, thus supporting the public policy proposal of enhanced bank disclosure, even in periods of banking crisis. However, changes in the regulatory environment over the last decade justify a re-investigation of the issue focusing on a more recent timeline. Moreover, it is worth differentiating the analysis by event type and testing the cause-effect relationship using a more robust methodology. Market reaction to supervisory sanctions is also reported in Ren (2015) that finds a negative market reaction to EAs for related party transactions from 2000-2013; however, this analysis refers to nonfinancial companies only and is limited to the effect on the Chinese stock market.

Recent empirical evidence on the relationship between EAs and market reaction in the US banking system comes from Zeidan (2013). Focusing on a sample of 128 publicly traded US banks that were subject to EAs over the period 1990-2009, Zeidan (2013) documents a significant negative market reaction to EAs, while the seriousness of the violation and the existence of multiple violations are found to be insignificant. Violating laws and regulations negatively affects the valuation of sanctioned banks as evident from the negative reaction documented in event studies. However, the analysis is limited to event study methodology, for a restricted event window, with no causal inference. Moreover, the analysis does not differentiate across EAs types, each of them representing different levels of severity, and therefore may lead to different market reactions. Therefore, it is important to further investigate the phenomenon by widening the scope of empirical investigation. 
We contribute to previous literature by providing new empirical evidence on the impact of US banks EAs on the equity market. We complement previous literature by using a wider sample and a more robust methodology; in addition to event study methodology introduced for a range of event windows, we test for cause-effect relationships between EAs and the market reaction for a recent time period. Further, we analyse a range of EA types and validate our analysis by testing across both sanctioned and comparable non-sanctioned banks. In line with previous literature, we expect equity market to react negatively to the announcement of EAs in the US banking system $\left(H_{1}\right)$.

\section{- $H_{1}$ : Equity market reacts negatively to the announcement of EAs on US banks.}

\subsection{Enforcement Actions and Depositors' Reaction}

Bank deposits are a crucial component of bank balance sheets and a field of existing literature investigates the factors affecting bank deposit growth. Within this field, the growth of deposits is found to be driven by both supply-side (income, inflation, interest rates, risk-reward profile of investment alternatives, demography, stability and trust in the banking sector) and demand-side components (regulation, competition, cost and availability of external funds) (Ahlswede and Schildbach 2012). Moreover, some literature documents bank disciplining power exercised by depositors. An empirical analysis on Russian banks over 2004-2006 (Semenova 2007) shows that depositors of private domestic banks discipline their banks by quantity (choosing bigger banks in terms of assets), by price and by switching from on-call to long-term deposits. Finger and Hesse (2009) examine the demand for commercial bank deposits in Lebanon and identifies macro(economic activity, price and interest differential) and micro-level factors (bank risk, liquidity, loan exposure, interest margin) affecting deposit demand. Berger and Turk-Arris (2015) find significant depositor discipline prior to the crisis for US and EU with a decline following the crisis except for small US banks; their results vary based on bank size and bank listing status. Davenport and McDill (2006) examine disciplinary behaviour of both insured and uninsured depositors for a failed bank between March 2001 and January 2002. Their findings confirm the existence of a depositor disciplining mechanism, thus extending previous literature on potential sources of depositor discipline to include fully insured depositors. However, none of the above studies analyse depositors' behaviour following formal sanctions enforced on their banks.

Within this field of research, it is interesting to investigate whether and how depositors react to the announcement of EAs. The earliest empirical evidence on this topic comes from Gilbert and Vaughan (2001) that measure depositors' reaction to 87 Federal Reserve EA announcements, by comparing deposit growth rates and yield spreads before and after the announcements for sanctioned banks and a control group of peer banks. Their results show that depositors do not care a great deal about EAs, and their study fails to document unusual deposit withdrawals or spread increases. This implies public announcements of EAs do not spark bank runs or enhance depositor discipline. However, their methodology is limited to mean deposit growth rate comparison and does not provide causality inference; therefore, it is worth investigating the phenomenon by widening the empirical investigation.

We extend previous literature by providing new empirical evidence on depositors' reaction to EA announcements. Our work differs from Gilbert and Vaughan (2001) in the sense that we use a wider and recent sample, and a more robust methodology to test depositors' reaction following EAs. Moreover, we complement previous literature by analysing a range of EA types and a set of depositor types. We extend previous literature by testing for causal between 
EA announcements and depositors' reaction, and validate our results across both sanctioned and comparable non-sanctioned banks using PSM methodology.

All deposits are characterized by some probability that the bank will not be able to repay due to default, however depositors' ability to change characteristics of their deposits in response to excessive risk-taking is questionable. Also, depositors would be unwilling to bring money to a bank which has uncertainty over its liquidity and solvency (Semenova 2007). At the same time, supervisors fear that, when negative information is released, depositors will panic and withdraw funds from the bank rather than evaluate the information carefully. In theory, depositors should respond by withdrawing funds or demanding higher returns on those funds (Gilbert and Vaughan 2001). In line with these arguments, we expect depositors to react negatively following EAs announcements affecting their banks $\left(\mathrm{H}_{2}\right)$.

- $\mathrm{H}_{2}$ : Depositors react negatively to the announcement of EAs on US banks.

\section{Methodology}

The aim of this section is to describe the methodology used for empirical analysis. Section 3.1 describes the sample selection process of EA announcements. Section 3.2 details the process for building the control group of non-sanctioned banks. Section 3.3 defines the event study methodology. Sections 3.4 and 3.5 present the methodology used to test market movement and depositors' reaction respectively.

\subsection{Sample Description: EA Announcements}

Data on formal EAs against banking institutions are manually collected from the websites of US supervisory authorities, namely the $\mathrm{FED}^{4}, \mathrm{OCC}^{5}$ and FDIC. ${ }^{6}$ This study focuses on, i) formal EAs that, differently from the informal actions, are publicly disclosed and ii) actions enforced on institutions operating in the US banking sector, without considering their affiliated parties. The timeline of analysis is January 2004 to August 2015 and includes three main types

\footnotetext{
${ }^{4}$ The Federal Reserve (FED) may take informal and formal EAs against entities it supervises and individuals affiliated with such entities for violations of laws, rules or regulations, unsafe or unsound practices, breaches of fiduciary duty, and violations of written commitments against state-chartered banks that are members of the Federal Reserve System; bank holding companies and their nonbank subsidiaries; branches and agencies of foreign banking organizations operating in the United States and their parent banks (Source: https://www. federalreserve.gov/supervisionreg/legal-developments.htm. URL last accessed on 23 April 2018).

${ }^{5}$ The Office of the Comptroller of the Currency (OCC) may take EAs for violations of laws, rules or regulations, final orders or conditions imposed in writing, unsafe or unsound practices and for breach of fiduciary duty by institution-affiliated parties (IAPs) against National banks, Federally chartered savings associations and their subsidiaries, Federal branches and agencies of foreign banks and IAPs, including officers, directors, employees, controlling stockholders, agents and certain other individuals (Source: https://www.occ.gov/topics/lawsregulations/enforcement-actions/index-enforcement-actions.html. URL last accessed on 23 April 2018).

6 The Federal Deposit Insurance Corporation (FDIC) pursues EAs against FDIC insured state chartered banks that are not members of the Federal Reserve System, FDIC insured branches of foreign banks and officers, directors, employees, controlling shareholders, agents and certain other categories of individuals (institution affiliated parties) associated with such institutions for violation of law, rules, unsafe or unsound banking practise, breaches of fiduciary duties and violation of final orders, conditions imposed in writing or written agreement (Source: https://www5.fdic.gov/EDO/index.html. URL last accessed on 23 April 2018).
} 
of sanctions: cease and desist orders $(\mathrm{C} \& \mathrm{D})^{7}$, orders assessing civil money penalties $(\mathrm{CMP})^{8}$ and formal agreements (FA). ${ }^{9}$

Table 1 summarises the sample selection process (Panel A) and the distribution of EAs by year (Panel B). In Panel A, the initial sample represents the EA events downloaded from the FED, OCC and FDIC, containing 956, 925 and 2096 EA announcements respectively. To evaluate the market reaction following the announcement of EAs, we exclude events for which neither the bank nor the parent is listed. Further, EAs are filtered to avoid duplication across the datasets. The above steps reduce the sample to 1526 EA announcements imposed on 423 unique banks over the period 2004-2015. The final sample of all banks collectively in our sample represents $61.39 \%$ of the US depository institutions in terms of total assets and $61.32 \%$ in terms of total deposits, as of 2015 . $^{10}$

Panel B shows the distribution of EAs over 2004-2015, highlighting some notable differences in the number of EAs across the years, with a peak in the announcements following the financial crisis. For the period 2004-2008, an average of 87 formal EAs against US banks were issued each year; as expected, EAs significantly increased in 2009 and 2010, reaching the highest number of 308 EAs within the period analysed. This peak in EA announcements can be attributed to the financial crisis that negatively affected US bank's capital, liquidity and performance (Srinivas et al. 2015). Specifically for C\&D, across the period 2008 to 2011, C\&D sanctions collectively account for $68.10 \%$ of the total C\&D EAs across the period of analysis. Since 2012, the number of EAs has started declining; this may be due to improved financial soundness and compliance, a more positive market environment, and the failure of many weak institutions (Vartanian and Schleusener 2012; Srinivas et al. 2015). Overall, majority of EA announcements in the final dataset is composed of C\&D (36.57\%) followed by CMP (36.04\%) and FA orders (27.39\%).

For the most recent year observed, i.e. 2015, the sample includes 36 EAs issued on 18 unique banks, representing $4.63 \%$ of the total listed US banks. ${ }^{11}$ Overall, similarly low percentages are found across years (i.e. $6.74 \%$ in 2014, 10.13\% in 2013), while showing a peak around the financial crisis period $(38.25 \%$ in $2010,37.64 \%$ in 2009$) .{ }^{12}$

\footnotetext{
${ }^{7}$ Supervisory authorities can pursue C\&D orders for actions that constitute unsafe and unsound banking practices, violations of federal or state laws and regulations, and violations of any written directive entered into with a banking agency. Apart from prohibiting certain types of practices, $C \& D$ usually require taking corrective actions. C\&D orders are made public and generate adverse publicity for the institution (Curry et al. 1999).

${ }^{8}$ Supervisory authorities can impose CMP for violations of laws, regulations, C\&D orders or other written agreements. The amount is proportional to the seriousness of the violations. The imposition of CMP is made public by regulators and may deter potential future violators (Curry et al. 1999).

${ }^{9}$ FA or Written agreement is a contract signed by the institution and the supervisory authority when circumstances warrant a less severe form of formal supervisory action. The agreement may relate to any of the problems found at the bank or involving affiliated parties.

${ }^{10}$ Industry data on depository institutions total assets and total deposits as of last quarter of 2015 is sourced from Federal Deposit Insurance Corporation statistics (Available at https://www5.fdic.gov/idasp/advSearch_warp_ download_all.asp?intTab=2. URL last accessed on 23 April 2018). Table reporting the sample representativeness for each year is not reported and available on request. This represents an approximate percentage as some banks may have fallen out of the sample due to various reasons (for e.g. merger, failure etc.).

${ }^{11}$ The total number of publicly traded US banks belonging to SIC code 60 is identified from Bloomberg database. The table reporting the percentage of unique bank IDs that have got an EA announcement each year is not reported and available on request.

${ }^{12}$ We thank the Editor for his suggestion of providing more clarity on the representativeness of the sample with respect to total number of publicly traded US banks.
} 
Table 1 Sample description of EA announcements

\begin{tabular}{|c|c|c|c|c|}
\hline \multicolumn{5}{|l|}{ Panel A- Sample Selection process } \\
\hline Database & FED & $\mathrm{OCC}$ & FDIC & Total \\
\hline EAs downloaded & 956 & 925 & 2096 & 3977 \\
\hline Neither Bank or Parent Listed & $(585)$ & $(453)$ & $(1248)$ & $(2286)$ \\
\hline Initial Sample & 371 & 472 & 848 & 1691 \\
\hline Removing duplicates & & & & $(165)$ \\
\hline Final Sample & & & & 1526 \\
\hline \multicolumn{5}{|l|}{ Panel B - List of EAs by year } \\
\hline Year & C\&D & CMP & FA & Total \\
\hline 2004 & 23 & 29 & 13 & 65 \\
\hline 2005 & 23 & 41 & 15 & 79 \\
\hline 2006 & 18 & 39 & 13 & 70 \\
\hline 2007 & 34 & 43 & 8 & 85 \\
\hline 2008 & 59 & 43 & 34 & 136 \\
\hline 2009 & 163 & 59 & 86 & 308 \\
\hline 2010 & 62 & 71 & 120 & 253 \\
\hline 2011 & 96 & 86 & 51 & 233 \\
\hline 2012 & 31 & 49 & 51 & 131 \\
\hline 2013 & 22 & 43 & 14 & 79 \\
\hline 2014 & 16 & 28 & 7 & 51 \\
\hline 2015 & 11 & 19 & 6 & 36 \\
\hline Total & 558 & 550 & 418 & 1526 \\
\hline$\%$ & 36.57 & 36.04 & 27.39 & 100 \\
\hline
\end{tabular}

This table presents the selected sample of EAs issued by FED, OCC and FDIC in the US banking system. Panel A details the sample selection process. Panel B lists EA announcements by year, from 2004 to 2015. Source of EA announcement data: authors' compilation from FED, OCC and FDIC websites.

\subsection{Estimation of Control Group}

We follow Rosenbaum and Rubin (1983) and use propensity-score matching (PSM) methodology to build a control group and enable comparative evaluations between sanctioned and non-sanctioned banks. The PSM process reduces potential sample selection bias and restricts inference to the sample of sanctioned banks (treatment group, denoted $\mathrm{T}_{i}=1$ for bank $i$ ) and non-sanctioned banks (control group, denoted $\mathrm{T}_{i}=0$ ). The treatment group is matched with the control group on the basis of propensity score which is a function of banks observable characteristics $\left(\mathrm{X}_{i}\right)$.

$$
P\left(X_{i}\right)=\operatorname{Prob}\left(T_{i}=1 \mid X_{i}\right) \text {, with }\left(0<P\left(X_{i}\right)<1\right)
$$

The matching process entails the following steps. First, we identify all active firms with SIC code starting with '60 - Depository Institution' within the US from the Bloomberg database. This group represents the control sample base ( $\mathrm{N}=876$ banks). Second, for each year starting from 2004, we remove banks that have been sanctioned the previous year from control sample base. For all the sanctioned (treated) banks and the remaining non-sanctioned ones (control sample base), we estimate the propensity scores through a probit model based on a list of bank characteristics (size, efficiency and profitability) a year before the EA announcement. Third, using the nearest neighbour matching technique (Guo and Jiang 2013; Gangl et al. 2014), we identify a control bank that has the closest propensity score to that of the treatment bank in that year, without replacement. This process is repeated every year until 2015. This estimation process identifies a one to one match for $1056 \mathrm{EA}$ announcements from the initial sample of $1526 .^{13}$

\footnotetext{
${ }^{13}$ Given the ubiquity of EAs, we do not match banks based on the type of supervisory authority. The authors acknowledge this as a limitation of the matching process and the analysis. We thank the Editor for highlighting this point.
} 


\subsection{Event Study Methodology}

To test the first research hypothesis $\left(H_{1}\right)$, an event study methodology is used to assess the effect of EA announcements on bank share price. For each sanctioned bank, the market reaction is measured by the cumulative average abnormal return (CAAR) around the announcement date using a standard market model (MacKinlay 1997; Ricci 2015).

$$
R_{i t}=a_{i}+b_{i} R_{m t}+e_{i t}
$$

Where $R_{i t}$ is the equity return for a bank ( $i$ ) for a given day $(t), R_{m t}$ is the return on the market for a given day $(t), e_{i t}$ is the white noise random component which is not correlated with $R_{m t}$ and is the statistical error term having an expected value $E\left(e_{i t}\right)=0$, with a constant variance Var $\left(e_{i t}\right)=\sigma_{e i}^{2}$ and $E\left(e_{i t}, e_{i, t-j}\right)=0$, for every $i \neq j, \alpha_{i}$ and $b_{i}$ are the model coefficients.

The $a_{i}$ and $b_{i}$ are estimated in an OLS regression setting using the daily log of share price returns obtained from Bloomberg. S\&P 500 returns are used as the market index and the econometric estimation is carried out over a 232 day estimation window, ending 20 days before the announcement date, i.e. period between 252 and 21 trading days prior to the announcement day. The above specification provides estimation for the parameters of normal period model which is not influenced by the event-related returns.

The estimated coefficients are replaced in Eqn. (2), to calculate the expected return $\hat{R}_{i t}$ for each firm $(i)$. Abnormal return $\left(A R_{i}\right)$ for each firm $(i)$ is derived using Eqn. (3),

$$
A R_{i t}=R_{i t}-\hat{R}_{i t}
$$

where $\hat{R}_{i t}=a_{i}+b_{i} R_{m t}$

The cumulative abnormal return $(C A R)$ is introduced to accommodate multiple sampling intervals within the event window and $C A R_{i}\left(t_{1} t_{2}\right)$ is the $C A R$ for security $(i)$ from $t_{1}$ to $t_{2}$ estimated as,

$$
C A R_{i}\left(t_{1}, t_{2}\right)=\sum_{t=t 1}^{t 2} A R_{i t}
$$

To aggregate $A R s$ across securities and through time, we assume no significant correlation across $A R s$ of the different securities. ${ }^{14}$ The average abnormal return $(A A R)$ for a given $t$ across securities is estimated as,

$$
A A R_{t}=\frac{1}{N} \sum_{i=1}^{N} A R_{i t}
$$

where $N$ is the number of banks that have actual equity return available for a given day $t$. To investigate the ongoing impact of an event on equity returns, $A A R$ is aggregated through time,

$$
C A A R_{\{t 1, t 2\}}=\sum_{t=t 1}^{t 2} A A R_{t}
$$

Where $C A A R_{\{t 1, t 2\}}$ is the cumulative average abnormal return for the period $\left\{\mathrm{t}_{1}, \mathrm{t}_{2}\right\}$. We focus on the following short event windows: 7 days $[-1 ;+5], 5$ days $[-1 ;+3], 3$ days $[-1 ;+1], 2$ days $[0 ;+1]$ and 1 day $[0]$ for event analysis.

\footnotetext{
${ }^{14}$ This is true in the absence of clustering, i.e. overlap in the event window of the included securities. The absence of overlap and the maintained distributional assumption imply that ARs will be independent across securities (Campbell et al. 1997).
} 
A series of parametric tests (standardised t $-Z_{O}, Z_{P}$ (Patell 1976) and $Z_{B}$ (Boehmer et al. 1991)) and non-parametric tests $\left(R_{T}\right.$ and $R_{Z}$ as estimates of rank test (Kolari and Pynnonen 2011) and $S_{C}$ (Cowan 1992) and $S_{T}$ (Corrado and Zivney 1992) as estimates of sign test) are applied to evaluate the statistical significance of $C A A R$.

\subsection{Market Reaction to EA Announcements}

To infer causality in the first research hypothesis $\left(H_{l}\right)$, we use OLS regression to examine the effect of sanction announcements on the equity market controlling for bank-specific, market and time period variables,

$C A R_{i, j}^{t_{1}, t_{2}}=\alpha+\sum_{1}^{j} \beta_{j} \operatorname{EVENT}_{i, j}+\sum_{1}^{k} \gamma_{k}$ BANK $_{i, k}+\sum_{1}^{h} \delta_{h} \operatorname{MARKET}_{h}+\sum_{1}^{n} \mu_{n} \operatorname{TIME}_{n}+\varepsilon_{i, j}^{t_{1}, t_{2}}$

where the dependent variable is the cumulative abnormal return (CAR) for the $i$-th bank and the $j$-th announcement over the event window $\left(t_{1}, t_{2}\right)$. Four variations of the event window, i.e. 1 day $[0], 2$ days $[0 ;+1], 3$ days $[-1 ;+1]$ and 5 days $[-1 ;+3]$, are tested in the regression model. $E V E N T$ is a vector of $j$ categorical variables identifying the type of EA announcement (C\&D_D, CMP_D and FA_D). BANK is a vector of $k$ bank-specific variables (TOTAL ASSET, $Z$ SCORE, EFFICIENCY, TIERI). MARKET is a vector of $h$ market variables (S\&P INDEX, $P M I)$. TIME identifies dummy variables for the periods related to the financial crisis (SUBPRIME_D, GLOBAL_D). Bank specific and market variables are collected from Bloomberg on a quarterly frequency.

For a robustness check, the analysis is repeated by comparing the sample of sanctioned (Tg) and non-sanctioned banks $(\mathrm{Cg})$,

$$
C A R_{i, j}^{t_{1}, t_{2}}=\alpha+\beta T Y P E_{-} D_{i}+\sum_{1}^{k} \gamma_{k} B A N K_{i, k}+\sum_{1}^{h} \delta_{h} M A R K E T_{h}+\sum_{1}^{n} \mu_{n} T_{I M E_{n}}+\varepsilon_{i, j}^{t_{1}, t_{2}}
$$

where TYPE_D is a dummy variable equal to 1 for $\mathrm{Tg}$ and 0 for $\mathrm{Cg}$; the other variables are similar to as in Eqn. (7).

One quarter lag of independent variables is used to control for endogeneity in the above regression models. A detailed description of the variables is reported in Table 2.

\subsection{Depositors' Reaction to EA Announcements}

To test the second research hypothesis $\left(\mathrm{H}_{2}\right)$, we investigate the effect of EA announcements on bank deposit growth using panel data fixed effect regression. ${ }^{15}$ Following the literature on bank deposit growth (i.e. Gilbert and Vaughan 2001; Finger and Hesse 2009) we control for bank specific and market variables,

$$
\text { DEPOSIT_GR } R_{i, t}=\alpha+\sum_{1}^{j} \beta_{j} E V E N T_{i, j, t-1}+\sum_{1}^{k} \gamma_{k} B A N K_{i, k, t-1}+\sum_{1}^{h} \delta_{h} M A R K E T_{h, t-1}+\varepsilon_{i, j}
$$

\footnotetext{
${ }^{15}$ The choice of the model is supported by Hausman test results which indicated a p-value of less than 0.05 hence supports the use of fixed regression model rather than random effect model.
} 
where the dependent variable is the deposit growth (DEPOSIT_GR) for the $i$-th bank at quarter $t$. Five specifications of the dependent variable are tested (TOTAL_DEP, SAVING_DEP, DEMAND_DEP, TIME_DEP, CORE_DEP). EVENT is a vector of $j$ variables identifying the type of EA announcements $\left(C \& D_{-} D, C M P_{-} D, F A \_D\right)$. BANK is a vector of $k$ bank-specific variables (EFFICIENCY, Z SCORE, TOTAL ASSET, NPLOANS, LOANS_GR). MARKET is a vector of $h$ market variables (GDP, $S \& P I N D E X)$. Bank specific and market variables are collected from Bloomberg on a quarterly frequency.

Fixed effect panel data regression is used to account for any time-invariant unobserved characteristics and one quarter lag of all independent variables is used to control for endogeneity in the regression model.

To enable comparison between the sample of sanctioned (Tg) and non-sanctioned banks $(\mathrm{Cg})$, we implement an OLS regression,

$$
\text { DEPOSIT_GR } R_{i}=\alpha+\beta T Y P E \_D_{i}+\sum_{1}^{k} \gamma_{k} B A N K_{i, k}+\sum_{1}^{h} \delta_{h} M A R K E T_{i, h}+\varepsilon_{i, j}
$$

where TYPE_D is a dummy variable equal to 1 for $\mathrm{Tg}$ and 0 for $\mathrm{Cg}$; the other variables are similar to as in Eqn. (9). A detailed description of the variables is reported in Table 2.

\section{Empirical Results}

This section discusses the main results. Section 4.1 presents the results from the event study analysis. Section 4.2 reports the findings from the analysis of market reaction to EAs. Section 4.3 discusses the results on depositors' reaction following EAs.

\subsection{Results from Event Study Analysis}

Table 3 presents the results from the event study analysis for banks that received EAs over the period 2004 to 2015. Cumulative average abnormal return (CAAR) is calculated across a range of event windows (7 days, 5 days, 3 days, 2 days and 1 day windows) and its significance is estimated across both parametric and non-parametric test statistics. Panel A reports CAAR across all events in the sample, while Panel B, Panel C and Panel D provide subsample analysis across the three types of events (C\&D, CMP, FA respectively).

Event study results show that CAAR is negative and significant when considering all events (Panel A) expect for the 1-day window, evidencing a significant and negative market reaction to EA announcements. However, the difference in market reaction becomes apparent when a sub-sample analysis is undertaken. Market reaction to $\mathrm{C} \& \mathrm{D}$ (Panel B) is negative and statistically significant across almost all the event windows analysed, indicating that equity markets react negatively following C\&D announcement except on the day of the announcement. Market reaction to CMP (Panel C) is significant only for the 2-day, 3-day and 5-day event windows; while market reaction to FA (Panel D) is surprisingly positive and significant on the day of FA announcement.

In a nutshell, the market reacts negatively to $\mathrm{C} \& \mathrm{D}$ and CMP announcements, while weak or no reaction is found following FA announcements. This implies that the equity market is able to discriminate EAs based on the severity of the sanction, by penalizing banks for more severe sanctions, i.e. C\&D and CMP, while reacting weakly for less severe sanction, i.e. FA. The 


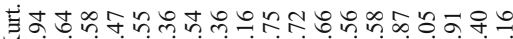

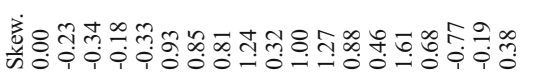

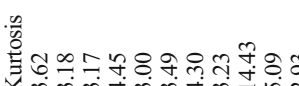

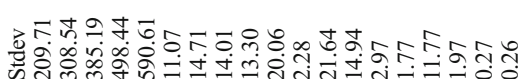

幽

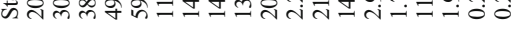

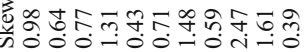

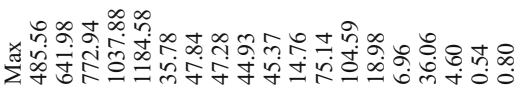

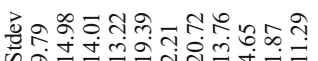

काल

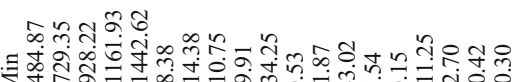

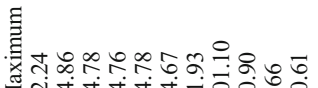

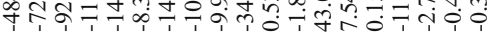

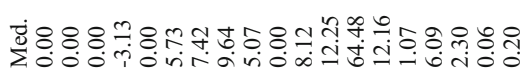

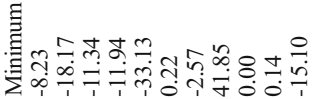

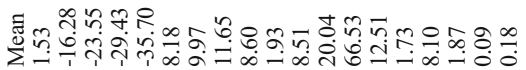

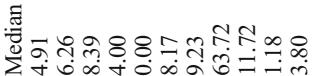

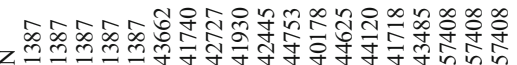

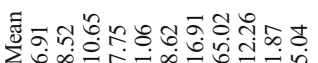

$8 \stackrel{8}{\circ}$

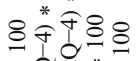

$* 0$.

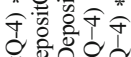

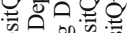

空.

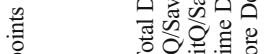

․․․

至

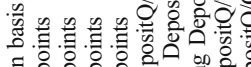

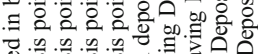

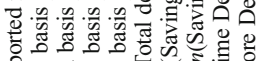

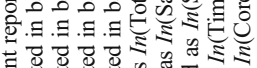

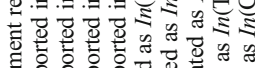

毒

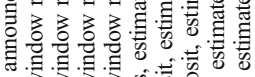

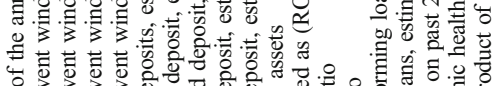

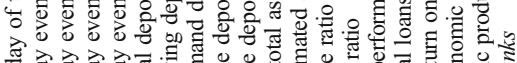

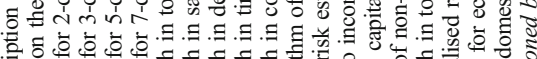

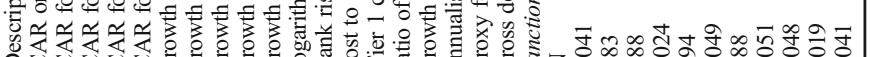

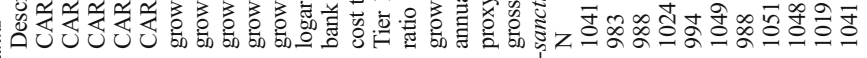

no bo

. 훌

난

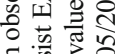

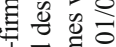

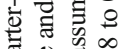

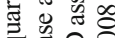

की

회워

究

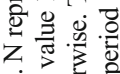

녕 छ

글

200

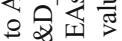

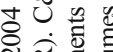

宅离

施

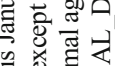

造

空苛

言

웜

항 항

产 ธี

च च

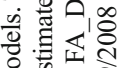

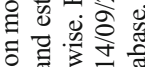

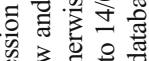

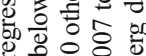

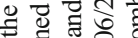

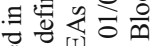

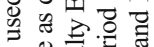

设 设

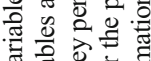

흄

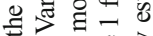

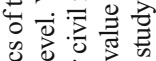

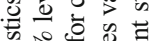

解定

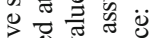

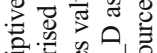

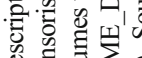

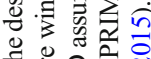

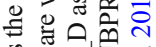

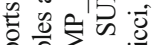

은. है

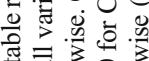

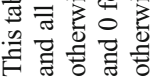


Table 3 Results from event study analysis

\begin{tabular}{|c|c|c|c|c|c|c|c|c|c|}
\hline \multirow{3}{*}{$\overline{\text { CAAR Window }}$} & \multirow[b]{3}{*}{$\mathrm{N}$} & \multirow[b]{3}{*}{$\mathrm{CAAR}\left[\mathrm{t}_{1} \mathrm{t}_{2}\right]$} & \multicolumn{3}{|c|}{ Parametric Test } & \multicolumn{4}{|c|}{ Non Parametric Test } \\
\hline & & & \multirow[b]{2}{*}{$\mathrm{Z}_{\mathrm{O}}$} & \multirow{3}{*}{$\mathrm{Z}_{\mathrm{P}}$} & \multirow[b]{2}{*}{$Z_{B}$} & \multicolumn{2}{|c|}{ Rank Test } & \multicolumn{2}{|c|}{ Sign test } \\
\hline & & & & & & $\mathrm{R}_{\mathrm{T}}$ & $\mathrm{R}_{\mathrm{Z}}$ & $\mathrm{S}_{\mathrm{C}}$ & $\mathrm{S}_{\mathrm{T}}$ \\
\hline \multicolumn{9}{|c|}{ Panel A - All Events } & \\
\hline$[-1,+5]$ & 1387 & $-54.25 * *$ & -1.46 & -1.48 & -1.46 & -1.29 & -1.80 & -1.31 & -1.29 \\
\hline$[-1,+3]$ & 1387 & $-57.39 * *$ & -1.76 & -1.75 & -1.76 & -1.41 & -1.96 & -1.95 & -1.40 \\
\hline$[-1,+1]$ & 1387 & $-36.93 *$ & -1.57 & -1.56 & -1.57 & -1.05 & -1.46 & -1.20 & -1.05 \\
\hline$[0,+1]$ & 1387 & $-25.08 * *$ & -1.30 & -1.30 & -1.30 & -1.25 & -1.74 & -1.46 & -1.24 \\
\hline$[0]$ & 1387 & 12.16 & 0.84 & 0.84 & 0.84 & -0.73 & -1.02 & -0.75 & -0.73 \\
\hline \multicolumn{10}{|c|}{ Panel B-Cease \& Desist Orders } \\
\hline$[-1,+5]$ & 504 & $-124.59^{*}$ & -1.61 & -1.54 & -1.61 & -1.51 & -1.06 & -0.83 & -1.51 \\
\hline$[-1,+3]$ & 504 & $-135.56^{* *}$ & -1.91 & -1.90 & -1.91 & -2.27 & -1.59 & -2.01 & -2.27 \\
\hline$[-1,+1]$ & 504 & $-76.49 * *$ & -1.82 & -1.81 & -1.82 & -2.07 & -1.45 & -1.88 & -2.07 \\
\hline$[0,+1]$ & 504 & $-26.63 *$ & -0.82 & -0.81 & -0.82 & -1.02 & -0.72 & -1.33 & -1.02 \\
\hline$[0]$ & 504 & 31.51 & 1.09 & 1.09 & 1.09 & -0.15 & -0.10 & -0.15 & -0.16 \\
\hline \multicolumn{10}{|c|}{ Panel C-Civil Money Penalty Orders } \\
\hline$[-1,+5]$ & 499 & -6.78 & -0.18 & -0.17 & -0.18 & -1.40 & -1.07 & -0.30 & -1.39 \\
\hline$[-1,+3]$ & 499 & $-32.02 *$ & -0.91 & -0.91 & -0.91 & -1.71 & -1.31 & -0.82 & -1.70 \\
\hline$[-1,+1]$ & 499 & $-21.42 *$ & -0.75 & -0.75 & -0.75 & -1.67 & -1.28 & -0.30 & -1.66 \\
\hline$[0,+1]$ & 499 & $-26.02 * *$ & -1.24 & -1.23 & -1.24 & -2.42 & -1.84 & -0.95 & -2.40 \\
\hline$[0]$ & 499 & -4.80 & -0.34 & -0.34 & -0.34 & -1.39 & -1.06 & -0.18 & -1.37 \\
\hline \multicolumn{10}{|c|}{ Panel D - Formal Agreements } \\
\hline$[-1,+5]$ & 384 & $-23.64 *$ & -0.33 & -0.39 & -0.33 & -1.93 & -1.22 & -1.16 & -1.93 \\
\hline$[-1,+3]$ & 384 & 12.22 & 0.22 & 0.22 & 0.22 & -0.54 & -0.34 & -0.47 & -0.54 \\
\hline$[-1,+1]$ & 384 & -5.18 & -0.10 & -0.10 & -0.10 & 0.18 & 0.12 & 0.23 & 0.18 \\
\hline$[0,+1]$ & 384 & -21.83 & -0.46 & -0.46 & -0.46 & -1.44 & -0.92 & -0.19 & -1.44 \\
\hline$[0]$ & 384 & $8.82 * *$ & 0.29 & 0.29 & 0.29 & -2.41 & -1.52 & -1.02 & -2.40 \\
\hline
\end{tabular}

This table presents the cumulative average abnormal returns $\left(\mathrm{CAAR}_{\{11, t 2\}}\right)$ for banks that received EAs over the period $01 / 01 / 2004-31 / 08 / 2015$. Event study methodology is applied across the following short event windows: 7 days $[-1 ;+5], 5$ days $[-1 ;+3], 3$ days $[-1 ;+1], 2$ days $[0 ;+1]$ and 1 day $[0]$ for event analysis. $\mathrm{N}$ is the number of banks that are used to estimate CAAR across the event windows. The significance of CAAR is estimated across a range of parametric $\left(Z_{0}, Z_{P}\right.$ and $\left.Z_{B}\right)$ and non-parametric tests (rank test - $R_{T}$ and $R_{Z}$, sign test - $S_{C}$ and $S_{T}$ ). Source: EA announcement data - author's compilation from FED, OCC and FDIC websites, share price - Bloomberg database.

The $* * *, * *$ and $*$ denote significance at $1 \%, 5 \%$ or $10 \%$ level respectively

magnitude of the coefficient, which represents the size of the reaction, is higher for C\&D with respect to other event types, confirming market reacts the most following $C \& D$ announcements. FA announcements are expected to be not as severe compared to C\&D and CMP. Moreover, FA announcements may also come as a relief for investors who would have been expecting a more negative sanction on the bank. Overall, the positive CAAR following the FA announcements may indicate investors' relief that the bank is given a lenient sanction without the need to shut down its operations or incur additional financial penalty.

The results from the event study are in line with previous literature that documents a negative market reaction following EA announcements (Brous and Legett 1996; Jordan et al. 1999; Zeidan 2013). The subsample analysis extends previous studies by highlighting different market reactions across the three event types.

However, event study analysis does not allow for inferring causality between EA events and market reaction. To evaluate if the equity market reaction is due to EA announcements, we 
undertake a multivariate analysis and develop a control group based on PSM methodology (Section 3.2), making the analysis more robust and extending previous literature in this field.

\subsection{Results from the Regression Models: Market Reaction to EAs}

Tables 4 presents the results from the OLS regression model (Eqn.7) investigating market reaction to EA announcements for sanctioned banks. We regress bank-specific and market variables on cumulative abnormal returns (CAR) estimated for each sanctioned bank across four event windows ( 1 day [0], 2 days $[0 ;+1], 3$ days $[-1 ;+1]$ and 5 days $[-1 ;+3])$.

The results from Table 4 highlight that the market reaction to C\&D announcements is negative and statistically significant (for 3-day and 5-day event windows), while a negative but not statistically significant reaction is documented for other event types. These results are in line with the findings from the event study analysis (Table 3). Among control variables, TOTAL ASSET and PMI have a positive and significant coefficient for the 5 day event window. There is no significantly effect of the crisis periods (GLOBAL_D AND SUBPRIME_D) on the CARs indicating market reactions following EA announcements are not statistically different from other periods. Overall, results in Table 4 complement the findings from event study (Table 3) as well as extend previous studies in this field (Brous and Leggett 1996; Jordan et al. 1999; Zeidan 2013) by validating the findings through a test of causality.

These results confirm hypothesis $H_{1}$ : the equity market reacts negatively to EA announcements on US banks. In particular, the equity market is sensitive to C\&D enforcement types and is able to discriminate EAs based on the severity of the sanction. Likewise, a weak or insignificant market reaction is found for the other event types. C\&D orders are well recognized as the more serious formal enforcement action, taken when a bank's prospects for failure are more than a remote possibility (Curry et al. 1999) and the above results are in line with our expectation. Moreover, a negative market reaction following C\&D announcements suggests that more severe EAs are not fully anticipated by the market.

For banks receiving sanctions, the existence of different market reactions based on the type of sanction highlights the need to consequently adopt different behaviours, i.e. whether to react or not following a sanction announcement, along with realigning their communication strategy based on the type of sanction to minimize reputational loss. No differential market reaction during periods of financial crisis indicates the effect is not dependent on external economic climate. From banking supervisors and other policy makers' perspectives, these results generate awareness of how the equity market would potentially react to different sanction announcements and would be relevant to guide further measures required when disclosing a formal EA. This would help to prevent panic among investors and other negative effects following EA announcements on banks and banks' stakeholders.

In Table 5, as a robustness check, the sample is extended by introducing the non-sanctioned banks (Eqn. 8). In Panel A, the event dummies are replaced by the dummy TYPE_D that assumes value 1 for $\mathrm{Tg}$ and 0 for $\mathrm{Cg}$. In Panel $\mathrm{B}$, to obtain a more comprehensive understanding of how various types of events differ between treated and control group, we introduce interactions between TYPE_D and the sanctions type (TYPE ${ }^{*} C \& D$ and $\left.T Y P E^{*} C M P^{16}\right)$. The results obtained from Table 4 are confirmed in Table 5. From Panel A, the main variable of

\footnotetext{
${ }^{16} T Y P E^{*} C \& D$ is the interaction between TYPE $D$ and $C \& D D$ D. TYPE*CMP is the interaction between $T Y P E \_D$ and $C M P \_D$. The interaction term TYPE $E^{*} F A$, between $T Y P E \_D$ and $F A \_D$, is omitted due to dummy variable trap. We thank an anonymous reviewer for suggesting this robustness check.
} 
Table 4 Regression results on market reaction to EAs

\begin{tabular}{lllll}
\hline Dep.var.: CAR & $(1)$ & $(2)$ & $(3)$ & $(4)$ \\
& CAR[0] & CAR[0,+1] & CAR[-1,+1] & CAR[-1,+3] \\
\hline C\&D_D & 16.74 & -72.91 & $-107.00^{*}$ & $-236.16^{* *}$ \\
CMP_D & $(38.784)$ & $(55.411)$ & $(62.707)$ & $(96.407)$ \\
& -19.36 & -44.64 & -34.02 & -109.89 \\
TOTAL_ASSET & $(35.404)$ & $(46.238)$ & $(52.093)$ & $(69.343)$ \\
& -2.35 & 3.23 & 7.01 & $19.34^{*}$ \\
ZSCORE & $(5.244)$ & $(7.587)$ & $(8.182)$ & $(11.284)$ \\
& 0.38 & 0.89 & 0.91 & 0.39 \\
EFFICIENCY & $(0.642)$ & $(0.905)$ & $(0.995)$ & $(1.254)$ \\
TIERI & 1.52 & -0.31 & -0.82 & -5.93 \\
& $(1.287)$ & $(1.729)$ & $(1.958)$ & $(3.677)$ \\
S\&P INDEX & 0.51 & 3.55 & 3.95 & 12.46 \\
& $(5.098)$ & $(7.092)$ & $(7.71)$ & $(11.742)$ \\
PMI & $-140.02^{* *}$ & -78.26 & -94.78 & -209.32 \\
SUBPRIME_D & $(54.745)$ & $(70.114)$ & $(79.156)$ & $(151.726)$ \\
GLOBAL_D & 2.8 & 6.96 & 8.69 & $20.64^{* *}$ \\
Constant & $(4.005)$ & $(6.049)$ & $(6.472)$ & $(9.566)$ \\
Adj. R-squared & 70.92 & 81.84 & 44.78 & 54.27 \\
Observations & $(44.999)$ & $(80.589)$ & $(82.548)$ & $(95.711)$ \\
\hline & $78.74 *$ & 12.61 & 2.88 & 0.22 \\
& $(41.753)$ & $(66.383)$ & $(71.095)$ & $(78.36)$ \\
& -235.88 & -405.68 & -489.62 & $-938.66^{*}$ \\
& $(249.969)$ & $(368.737)$ & $(389.235)$ & $(533.363)$ \\
& $1.74 \%$ & $0.82 \%$ & $1.23 \%$ & $3.53 \%$ \\
& 1072 & 1072 & 1072 & 1072 \\
\hline
\end{tabular}

This table reports results from OLS regression investigating market reaction to the announcement of EAs. Market reaction is measured by cumulative abnormal returns (CAR) across four event windows: 1 day [0], 2 days $[0 ;+1]$, 3 days $[-1 ;+1]$ and 5 days $[-1 ;+3]$. Variables are defined in Table 2 and one quarter lag of independent variables is used. Robust standard errors are reported in parenthesis under each coefficient. Source: event study analysis and Bloomberg database.

The $* * *, * *$ and $*$ denote significance at $1 \%, 5 \%$ or $10 \%$ level respectively.

interest, TYPE_ $D$, is negative and statistically significant for the 1-day event window while not significant for others, suggesting that the market reacts negatively to EA announcements for sanctioned banks compared to the matched non-sanctioned banks, although the effect is short lived. Results from Panel B confirm equity market sensitivity following C\&D announcements with respect to other event types.

\subsection{Results from the Regression Models: Depositors' Reaction to EAs}

Table 6 reports results from the regression model in Eqn. (9) assessing depositors' reaction following EA announcements for the sample of sanctioned banks. A fixed effect panel data regression is used to ascertain if depositors react to EA announcements. To this purpose, different measures of deposit growth are considered: growth in total deposits (Table 6, column 1), growth in saving deposits (Table 6, column 2), growth in demand deposits (Table 6, column 3 ), growth in time deposits (Table 6, column 4) and growth in core deposits (Table 6, column 5). The difference in the types of deposits provides an indication of the reaction associated with the type of depositor at the sanctioned bank.

From Table 6, considering the growth in all types of deposits collectively, the quarters following C\&D, CMP and FA announcements show a significant increase in bank deposits. To 
Table 5 Regression results on market reaction to $\mathrm{EAs}-\mathrm{Tg}$ and $\mathrm{Cg}$

\begin{tabular}{|c|c|c|c|c|}
\hline Dep.var: $C A R$ & $\begin{array}{l}\text { (1) } \\
\text { CAR[0] }\end{array}$ & $\begin{array}{l}(2) \\
\text { CAR }[0,+1]\end{array}$ & $\begin{array}{l}\text { (3) } \\
\text { CAR }[-1,+1]\end{array}$ & $\begin{array}{l}\text { (4) } \\
\text { CAR }[-1,+3]\end{array}$ \\
\hline \multicolumn{5}{|c|}{ Panel A - OLS Regression } \\
\hline TYPE_D & $\begin{array}{l}-13.29 * * \\
(6.527)\end{array}$ & $\begin{array}{l}-14.68 \\
(9.918)\end{array}$ & $\begin{array}{l}-5.85 \\
(12.189)\end{array}$ & $\begin{array}{l}2.51 \\
(15.597)\end{array}$ \\
\hline TOTAL ASSET & $\begin{array}{l}-1.68 \\
(1.525)\end{array}$ & $\begin{array}{l}-1.85 \\
(2.339)\end{array}$ & $\begin{array}{l}-1.23 \\
(2.747)\end{array}$ & $\begin{array}{l}1.34 \\
(3.651)\end{array}$ \\
\hline Z SCORE & $\begin{array}{l}-0.25 \\
(0.169)\end{array}$ & $\begin{array}{l}0.08 \\
(0.247)\end{array}$ & $\begin{array}{l}0.29 \\
(0.296)\end{array}$ & $\begin{array}{l}0.13 \\
(0.382)\end{array}$ \\
\hline EFFICIENCY & $\begin{array}{l}-0.31 \\
(0.261)\end{array}$ & $\begin{array}{l}-0.75^{*} \\
(0.411)\end{array}$ & $\begin{array}{l}-0.61 \\
(0.505)\end{array}$ & $\begin{array}{l}-0.89 \\
(0.65)\end{array}$ \\
\hline TIER1 & $\begin{array}{l}-0.13 \\
(1.023)\end{array}$ & $\begin{array}{l}1.65 \\
(1.556)\end{array}$ & $\begin{array}{l}2.33 \\
(1.934)\end{array}$ & $\begin{array}{l}1.64 \\
(2.473)\end{array}$ \\
\hline$S \& P$ INDEX & $\begin{array}{l}-34.55 * * * \\
(11.675)\end{array}$ & $\begin{array}{l}-37.95 * * \\
(18.038)\end{array}$ & $\begin{array}{l}-41.23^{*} \\
(22.176)\end{array}$ & $\begin{array}{l}-69.52 * * \\
(28.035)\end{array}$ \\
\hline$P M I$ & $\begin{array}{l}1.75^{* *} \\
(0.801)\end{array}$ & $\begin{array}{l}1.66 \\
(1.224)\end{array}$ & $\begin{array}{l}3.2 * * \\
(1.506)\end{array}$ & $\begin{array}{l}3.87 * * \\
(1.909)\end{array}$ \\
\hline SUBPRIME_D & $\begin{array}{l}25.03^{*} \\
(13.623)\end{array}$ & $\begin{array}{l}18.14 \\
(20.442)\end{array}$ & $\begin{array}{l}9.84 \\
(24.583)\end{array}$ & $\begin{array}{l}14.04 \\
(30.962)\end{array}$ \\
\hline$G L O B A L \_D$ & $\begin{array}{l}23.09 * * \\
(9.145)\end{array}$ & $\begin{array}{l}11.88 \\
(13.583)\end{array}$ & $\begin{array}{l}6.87 \\
(16.905)\end{array}$ & $\begin{array}{l}12.36 \\
(21.847)\end{array}$ \\
\hline Constant & $\begin{array}{l}-43.44 \\
(53.679)\end{array}$ & $\begin{array}{l}-43.84 \\
(81.489)\end{array}$ & $\begin{array}{l}-164.39 \\
(100.522)\end{array}$ & $\begin{array}{l}-205.24 \\
(127.771)\end{array}$ \\
\hline Adj. R-squared & $1.34 \%$ & $0.88 \%$ & $0.83 \%$ & $0.77 \%$ \\
\hline Observations & 1958 & 1958 & 1958 & 1958 \\
\hline \multicolumn{5}{|c|}{ Panel B - OLS Regression with interactions } \\
\hline$T Y P E^{*} C \& D$ & $\begin{array}{l}19.23 \\
(12.67)\end{array}$ & $\begin{array}{l}-21.96 \\
(19.389)\end{array}$ & $\begin{array}{l}-43.54^{*} \\
(23.667)\end{array}$ & $\begin{array}{l}-65.87 * * \\
(29.84)\end{array}$ \\
\hline$T Y P E^{*} C M P$ & $\begin{array}{l}1.6 \\
(11.994)\end{array}$ & $\begin{array}{l}-7.24 \\
(18.091)\end{array}$ & $\begin{array}{l}-5.73 \\
(22.707)\end{array}$ & $\begin{array}{l}-27.5 \\
(29.213)\end{array}$ \\
\hline TOTAL ASSET & $\begin{array}{l}-0.48 \\
(2.156)\end{array}$ & $\begin{array}{l}-0.38 \\
(3.5)\end{array}$ & $\begin{array}{l}2.26 \\
(4.119)\end{array}$ & $\begin{array}{l}9.46^{*} \\
(5.485)\end{array}$ \\
\hline Z SCORE & $\begin{array}{l}-0.04 \\
(0.264)\end{array}$ & $\begin{array}{l}0.49 \\
(0.382)\end{array}$ & $\begin{array}{l}0.99 * * \\
(0.46)\end{array}$ & $\begin{array}{l}0.55 \\
(0.589)\end{array}$ \\
\hline EFFICIENCY & $\begin{array}{l}-0.23 \\
(0.375)\end{array}$ & $\begin{array}{l}-0.87 \\
(0.589)\end{array}$ & $\begin{array}{l}-0.7 \\
(0.716)\end{array}$ & $\begin{array}{l}-1.66^{*} \\
(0.895)\end{array}$ \\
\hline TIER1 & $\begin{array}{l}-0.35 \\
(1.546)\end{array}$ & $\begin{array}{l}1.62 \\
(2.34)\end{array}$ & $\begin{array}{l}3.51 \\
(2.964)\end{array}$ & $\begin{array}{l}2.07 \\
(3.846)\end{array}$ \\
\hline$S \& P I N D E X$ & $\begin{array}{l}-44.82 * * * \\
(17.204)\end{array}$ & $\begin{array}{l}-40.9 \\
(26.888)\end{array}$ & $\begin{array}{l}-46.4 \\
(33.353)\end{array}$ & $\begin{array}{l}-71.06^{*} \\
(41.275)\end{array}$ \\
\hline$P M I$ & $\begin{array}{l}1.88 \\
(1.192)\end{array}$ & $\begin{array}{l}1.06 \\
(1.844)\end{array}$ & $\begin{array}{l}2.09 \\
(2.277)\end{array}$ & $\begin{array}{l}2.7 \\
(2.862)\end{array}$ \\
\hline SUBPRIME_D & $\begin{array}{l}37.09 * \\
(21.041)\end{array}$ & $\begin{array}{l}20.92 \\
(30.874)\end{array}$ & $\begin{array}{l}6.78 \\
(37.12)\end{array}$ & $\begin{array}{l}-4.57 \\
(47.6)\end{array}$ \\
\hline$G L O B A L \_D$ & $\begin{array}{l}25.78^{*} \\
(13.861)\end{array}$ & $\begin{array}{l}2.38 \\
(20.687)\end{array}$ & $\begin{array}{l}-9.39 \\
(26)\end{array}$ & $\begin{array}{l}-10.49 \\
(33.636)\end{array}$ \\
\hline Constant & $\begin{array}{l}-86.67 \\
(82.278)\end{array}$ & $\begin{array}{l}-22.85 \\
(125.87)\end{array}$ & $\begin{array}{l}-136.81 \\
(155.708)\end{array}$ & $\begin{array}{l}-129.14 \\
(197.153)\end{array}$ \\
\hline Adj. R-squared & $1.93 \%$ & $1.51 \%$ & $2.36 \%$ & $2.50 \%$ \\
\hline Observations & 971 & 971 & 971 & 971 \\
\hline
\end{tabular}

This table reports results of OLS regression of market reaction to the announcement of EAs, by comparing the sample of sanctioned banks ( $\mathrm{Tg}$ ) with non-sanctioned banks ( $\mathrm{Cg})$. The control group is estimated by applying PSM methodology and nearest neighbour matching estimation, as explained in Section 3.2. Market reaction is measured by cumulative abnormal returns (CAR) across four event windows: 1 day [0], 2 days [0;+1], 3 days [$1 ;+1]$ and 5 days $[-1 ;+3]$. Variables are defined in Table 2 and one quarter lag of independent variables is used. Panel A investigates the effect of TYPE_D on CAR, while Panel B introduces interaction terms between TYPE_D and event types $\left(T Y P E^{*} C \& D\right.$ and $\left.T Y P E^{*} C M P\right)$. Robust standard errors are reported in parenthesis under each coefficient. Source: event study analysis and Bloomberg database.

The $* * *, * *$ and $*$ denote significance at $1 \%, 5 \%$ or $10 \%$ level respectively. 
Table 6 Regression results on depositors' reaction to EAs

\begin{tabular}{|c|c|c|c|c|c|}
\hline Dep.var:DEPOSIT_GR & $\begin{array}{l}\text { (1) } \\
\text { TOTAL_DEP }\end{array}$ & $\begin{array}{l}\text { (2) } \\
\text { SAVING_DEP }\end{array}$ & $\begin{array}{l}\text { (3) } \\
\text { DEMAND_DEP }\end{array}$ & $\begin{array}{l}\text { (4) } \\
\text { TIME_DEP }\end{array}$ & $\begin{array}{l}(5) \\
\text { CORE_DEP }\end{array}$ \\
\hline$C \& D \_D$ & $\begin{array}{l}0.97 * \\
(0.528)\end{array}$ & $\begin{array}{l}0.68 \\
(0.905)\end{array}$ & $\begin{array}{l}-1.95 * * * \\
(0.699)\end{array}$ & $\begin{array}{l}0.86 \\
(0.767)\end{array}$ & $\begin{array}{l}2.54 * * \\
(0.996)\end{array}$ \\
\hline$C M P \_D$ & $\begin{array}{l}1.13 * * \\
(0.478)\end{array}$ & $\begin{array}{l}-0.55 \\
(0.735)\end{array}$ & $\begin{array}{l}0.57 \\
(0.634)\end{array}$ & $\begin{array}{l}0.70 \\
(0.681)\end{array}$ & $\begin{array}{l}2.66 * * \\
(1.033)\end{array}$ \\
\hline$F A \_D$ & $\begin{array}{l}1.64 * * * \\
(0.579)\end{array}$ & $\begin{array}{l}3.36 * * * \\
(0.84)\end{array}$ & $\begin{array}{l}1.10 \\
(0.89)\end{array}$ & $\begin{array}{l}2.23 * * \\
(0.886)\end{array}$ & $\begin{array}{l}1.57 \\
(1.056)\end{array}$ \\
\hline EFFICIENCY & $\begin{array}{l}0.01 \\
(0.007)\end{array}$ & $\begin{array}{l}-0.02 * \\
(0.012)\end{array}$ & $\begin{array}{l}0.06^{* * * *} \\
(0.01)\end{array}$ & $\begin{array}{l}-0.01 \\
(0.01)\end{array}$ & $\begin{array}{l}-0.08 * * * \\
(0.015)\end{array}$ \\
\hline Z SCORE & $\begin{array}{l}-0.03 * * * \\
(0.004)\end{array}$ & $\begin{array}{l}-0.05 * * * \\
(0.006)\end{array}$ & $\begin{array}{l}-0.06 * * * \\
(0.005)\end{array}$ & $\begin{array}{l}-0.04 * * * \\
(0.005)\end{array}$ & $\begin{array}{l}-0.01 \\
(0.008)\end{array}$ \\
\hline TOTAL ASSET & $\begin{array}{l}-0.46 * * \\
(0.201)\end{array}$ & $\begin{array}{l}1.39 * * * \\
(0.353)\end{array}$ & $\begin{array}{l}6.51 * * * \\
(0.393)\end{array}$ & $\begin{array}{l}-1.40 * * * \\
(0.369)\end{array}$ & $\begin{array}{l}-9.12 * * * \\
(0.52)\end{array}$ \\
\hline NPLOANS & $\begin{array}{l}0.27 * * * \\
(0.064)\end{array}$ & $\begin{array}{l}1.48 * * * \\
(0.121)\end{array}$ & $\begin{array}{l}1.45^{* * * *} \\
(0.102)\end{array}$ & $\begin{array}{l}1.16^{* * * *} \\
(0.1)\end{array}$ & $\begin{array}{l}-0.97 * * * \\
(0.152)\end{array}$ \\
\hline LOANS_GR & $\begin{array}{l}0.58 * * * \\
(0.007)\end{array}$ & $\begin{array}{l}0.50 * * * \\
(0.011)\end{array}$ & $\begin{array}{l}0.45 * * * \\
(0.01)\end{array}$ & $\begin{array}{l}0.53 * * * \\
(0.012)\end{array}$ & $\begin{array}{l}0.79 * * * \\
(0.019)\end{array}$ \\
\hline$G D P$ & $\begin{array}{l}-1.09 * * * \\
(0.133)\end{array}$ & $\begin{array}{l}-1.87 * * * \\
(0.188)\end{array}$ & $\begin{array}{l}-2.31 * * * \\
(0.185)\end{array}$ & $\begin{array}{l}-1.69 * * * \\
(0.18)\end{array}$ & $\begin{array}{l}1.06 * * * \\
(0.304)\end{array}$ \\
\hline$S \& P I N D E X$ & $\begin{array}{l}0.02 \\
(0.029)\end{array}$ & $\begin{array}{l}0.34 * * * \\
(0.051)\end{array}$ & $\begin{array}{l}0.93 * * * \\
(0.042)\end{array}$ & $\begin{array}{l}0.20 * * * \\
(0.042)\end{array}$ & $\begin{array}{l}-0.76 * * * \\
(0.055)\end{array}$ \\
\hline Constant & $\begin{array}{l}8.00 * * * \\
(1.791)\end{array}$ & $\begin{array}{l}-6.33 * * \\
(2.937)\end{array}$ & $\begin{array}{l}-54.74 * * * \\
(3.479)\end{array}$ & $\begin{array}{l}16.55 * * * \\
(3.34)\end{array}$ & $\begin{array}{l}82.90 * * * \\
(4.675)\end{array}$ \\
\hline $\begin{array}{l}\text { Adj. R-square } \\
\text { Observations }\end{array}$ & $\begin{array}{l}34.45 \% \\
37710\end{array}$ & $\begin{array}{l}13.45 \% \\
36375\end{array}$ & $\begin{array}{l}18.30 \% \\
37084\end{array}$ & $\begin{array}{l}16.79 \% \\
36681\end{array}$ & $\begin{array}{l}25.96 \% \\
36862\end{array}$ \\
\hline
\end{tabular}

This table reports results from fixed effect panel data regression investigating depositors' reaction to the announcement of EAs. Depositors' reaction is measured as growth in total, saving, demand, time and core deposits. Variables are defined in Table 2, one quarter lag of independent variables is used and observations are on quarter-firm basis. Robust standard errors are reported in parenthesis under each coefficient. Source: Bloomberg database.

The $* * *, * *$ and $*$ denote significance at $1 \%, 5 \%$ or $10 \%$ level respectively.

provide a more accurate interpretation of this result, it is important to distinguish the reaction based on the type of sanction and the type of deposits, as depositors could exhibit a different behaviour following a particular EA.

Looking at demand deposits (Table 6, column 3), a negative and highly significant coefficient for $C \& D_{-} D$ indicates demand deposits holders reduce their deposits in sanctioned banks in quarters following C\&D announcements. However, no such effect can be observed for quarters following CMP and FA announcements. Demand depositors have the liberty to move their deposits without incurring any financial penalty and the reduction in deposits may indicate depositors disciplining their banks following a severe sanction announcement (Gilbert and Vaughan 2001). A positive and significant coefficient is found for savings deposits following FA_D announcements (Table 6, column 2) and following $C \& D \_D$ and $C M P \_D$ announcements for core deposits (Table 6, column 5 ). This set of results confirm our hypothesis $H_{2}$ but only for $C \& D_{-} D$ in case of demand deposits and are in line with previous literature expecting depositors to respond unfavourably to EAs by panicking and withdrawing funds from their sanctioned bank, i.e. depositor disciplining mechanism (i.e. Gilbert and Vaughan 2001; Davenport and McDill, 2006; Semenova 2007). However, $H_{2}$ is not confirmed across the remaining measures of deposit growth. 
In fact, when considering growth in core deposits (Table 6, column 5), the coefficients for $C \& D \_D$ and $C M P \_D$ are positive and significant, indicating an apparent positive attitude towards the sanctioned banks. This could be attributed to a possible strategy adopted by the sanctioned bank following an EA announcement, i.e. either the sanctioned banks increase the interest offering to attract more core depositors to compensate for the (anticipated) negative market reaction or current depositors expect their sanctioned banks to offer better risk-adjusted returns in terms of higher interest rates and hence the anticipated growth. In support of this, previous literature has shown that deposit holders at thrift institutions respond to increases in the probability of bank failure by demanding higher returns (Park and Peristiani 1998). An alternative explanation for the positive $C \& D \_D$ and $C M P \_D$ coefficient for core deposits is explained in Gilbert and Vaughan (2001), where borrowers could interpret $C \& D$ announcement as a signal that the bank has loose credit standards and flood it with increased loan demand, causing sanctioned banks to attract additional deposits to fund new loans, causing a rise in deposit levels.

The positive and significant coefficient for FA_D (Table 6, columns 1,2 and 4) when considering growth in total, saving and time deposits can be explained in the context of FA sanctions, which are less severe compared to the other two types of sanctions. Depositors may consider FA announcement as more of a corrective action on their bank without the need to cease existing operations or incur financial penalty. Consequently, following an FA announcement, depositors consider their bank to be more sound and hence the potential increase in deposits for the sanctioned banks. This result corroborates our findings in Table 3 (event study analysis) showing positive market reaction, due to depositors expecting FA announcement to be a corrective mechanism.

These results show that the announcement of EAs by bank regulators which is circulated by media represents an important source of information for depositors to form a perception and consequently alter their deposit accounts at the sanctioned banks.

In Table 7, as a robustness check, we undertake a comparative analysis between $\mathrm{Tg}$ and $\mathrm{Cg}$ (Eqn. 10). In Panel $\mathrm{A}$, the event dummies are replaced by the dummy TYPE_ $D$ that assumes value 1 for $\mathrm{Tg}$ and 0 for $\mathrm{Cg}$. In Panel B, we introduce interactions between TYPE_D and the sanctions type $\left(T Y P E^{*} C \& D\right.$ and $\left.T Y P E^{*} C M P\right){ }^{17}$ The results obtained from Table 7 corroborate the findings in Table 6. From Panel A, the coefficient for TYPE_D is positive and significant for growth in total and core deposits while negative and significant for growth in demand deposits. The results indicate a positive growth in total and core deposits and a negative growth in demand deposits for one quarter following the EA announcement for sanctioned bank in comparison to a similar matched nonsanctioned bank when all EAs are considered collectively. Results from Panel B, partially supports the above findings. For sanctioned banks following C\&D and CMP announcements, there is negative growth in demand and saving deposits; however these dummy variables lose significance for core deposits, indicating the relationship is not statistically significant when looked at the core deposits growth for sanctioned banks. As a further robustness check to ensure the reliability of the results, the two-quarter lead of deposit growth is used to test if the effect on deposit growth is persistent over two subsequent quarters. The results not reported here are consistent to those in Tables 6 and 7.

Overall, the above results indicate that EA announcements could cause a positive or negative growth in bank deposits depending on the type of deposit and the type of EA being considered. In particular, savings and demand deposits show significant negative effects for sanctioned firms following $C \& D$ and $C M P$ announcements.

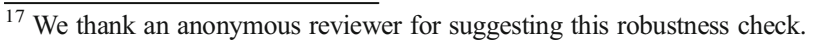


Table 7 Regression results on depositors' reaction to $\mathrm{EAs}-\mathrm{Tg}$ and $\mathrm{Cg}$

\begin{tabular}{|c|c|c|c|c|c|}
\hline Dep.var:: DEPOSIT_GR & $\begin{array}{l}\text { (1) } \\
\text { TOTAL_DEP }\end{array}$ & $\begin{array}{l}\text { (2) } \\
\text { SAVING_DEP }\end{array}$ & $\begin{array}{l}\text { (3) } \\
\text { DEMAND_DEP }\end{array}$ & $\begin{array}{l}\text { (4) } \\
\text { TIME_DEP }\end{array}$ & $\begin{array}{l}\text { (5) } \\
\text { CORE_DEP }\end{array}$ \\
\hline \multicolumn{6}{|l|}{ Panel A - OLS Regression } \\
\hline TYPE_D & $\begin{array}{l}0.96 \text { *** } \\
(0.361)\end{array}$ & $\begin{array}{l}1.02 \\
(0.695)\end{array}$ & $\begin{array}{l}-1.32 * * \\
(0.619)\end{array}$ & $\begin{array}{l}0.59 \\
(0.589)\end{array}$ & $\begin{array}{l}2.01 * * \\
(0.806)\end{array}$ \\
\hline EFFICIENCY & $\begin{array}{l}-0.01 \\
(0.017)\end{array}$ & $\begin{array}{l}-0.13 * * * \\
(0.031)\end{array}$ & $\begin{array}{l}0.003 \\
(0.027)\end{array}$ & $\begin{array}{l}-0.01 \\
(0.027)\end{array}$ & $\begin{array}{l}0.001 \\
(0.033)\end{array}$ \\
\hline Z SCORE & $\begin{array}{l}-0.06 * * * \\
(0.009)\end{array}$ & $\begin{array}{l}-0.11 * * * \\
(0.018)\end{array}$ & $\begin{array}{l}-0.08 * * * \\
(0.016)\end{array}$ & $\begin{array}{l}-0.08 * * * \\
(0.015)\end{array}$ & $\begin{array}{l}-0.06 * * * \\
(0.021)\end{array}$ \\
\hline TOTAL ASSET & $\begin{array}{l}0.25 * * * \\
(0.087)\end{array}$ & $\begin{array}{l}-0.04 \\
(0.173)\end{array}$ & $\begin{array}{l}0.86 * * * \\
(0.175)\end{array}$ & $\begin{array}{l}0.97 * * * \\
(0.169)\end{array}$ & $\begin{array}{l}-0.4 * \\
(0.207)\end{array}$ \\
\hline NPLOANS & $\begin{array}{l}0.06 \\
(0.13)\end{array}$ & $\begin{array}{l}0.37 \\
(0.244)\end{array}$ & $\begin{array}{l}0.65 * * * \\
(0.218)\end{array}$ & $\begin{array}{l}0.06 \\
(0.21)\end{array}$ & $\begin{array}{l}-0.07 \\
(0.276)\end{array}$ \\
\hline LOANS_GR & $\begin{array}{l}0.6 * * * \\
(0.021)\end{array}$ & $\begin{array}{l}0.44 * * * \\
(0.038)\end{array}$ & $\begin{array}{l}0.52 * * * \\
(0.034)\end{array}$ & $\begin{array}{l}0.43 * * * \\
(0.038)\end{array}$ & $\begin{array}{l}0.88 * * * \\
(0.043)\end{array}$ \\
\hline$G D P$ & $\begin{array}{l}0.01 \\
(0.079)\end{array}$ & $\begin{array}{l}0.61 * * * \\
(0.149)\end{array}$ & $\begin{array}{l}0.86^{* * * *} \\
(0.129)\end{array}$ & $\begin{array}{l}-0.08 \\
(0.124)\end{array}$ & $\begin{array}{l}-0.77 * * * \\
(0.165)\end{array}$ \\
\hline$S \& P I N D E X$ & $\begin{array}{l}1.88 * * * \\
(0.556)\end{array}$ & $\begin{array}{l}0.96 \\
(1.069)\end{array}$ & $\begin{array}{l}-0.66 \\
(0.955)\end{array}$ & $\begin{array}{l}1.86 * * \\
(0.932)\end{array}$ & $\begin{array}{l}1.89 \\
(1.195)\end{array}$ \\
\hline Constant & $\begin{array}{l}3.4 * * \\
(1.455)\end{array}$ & $\begin{array}{l}16.05 * * * \\
(2.944)\end{array}$ & $\begin{array}{l}0.56 \\
(2.586)\end{array}$ & $\begin{array}{l}-0.74 \\
(2.524)\end{array}$ & $\begin{array}{l}2.02 \\
(3.123)\end{array}$ \\
\hline Adj. R-square & $43.47 \%$ & $12.63 \%$ & $17.88 \%$ & $15.17 \%$ & $26.32 \%$ \\
\hline Observations & 1908 & 1817 & 1830 & 1833 & 1847 \\
\hline \multicolumn{6}{|c|}{ Panel B - OLS regressions with interaction } \\
\hline$T Y P E^{*} C \& D$ & $\begin{array}{l}-0.47 \\
(0.66)\end{array}$ & $\begin{array}{l}-3.85 * * * \\
(1.264)\end{array}$ & $\begin{array}{l}-3.5 * * * \\
(1.121)\end{array}$ & $\begin{array}{l}-0.44 \\
(1.129)\end{array}$ & $\begin{array}{l}1.51 \\
(1.39)\end{array}$ \\
\hline$T Y P E^{*} C M P$ & $\begin{array}{l}-1.05 * \\
(0.615)\end{array}$ & $\begin{array}{l}-4.73 * * * \\
(1.207)\end{array}$ & $\begin{array}{l}-2.43 * * \\
(1.087)\end{array}$ & $\begin{array}{l}-1.09 \\
(1.07)\end{array}$ & $\begin{array}{l}1.63 \\
(1.449)\end{array}$ \\
\hline EFFICIENCY & $\begin{array}{l}-0.04 * \\
(0.023)\end{array}$ & $\begin{array}{l}-0.14 * * * \\
(0.042)\end{array}$ & $\begin{array}{c}-0.08 * * \\
(0.036)\end{array}$ & $\begin{array}{c}-0.08^{* * *} \\
(0.036)\end{array}$ & $\begin{array}{l}0.003 \\
(0.044)\end{array}$ \\
\hline Z SCORE & $\begin{array}{l}-0.07 * * * \\
(0.014)\end{array}$ & $\begin{array}{l}-0.14 * * * \\
(0.027)\end{array}$ & $\begin{array}{l}-0.05 * * \\
(0.025)\end{array}$ & $\begin{array}{l}-0.08 * * * \\
(0.024)\end{array}$ & $\begin{array}{l}-0.05^{*} \\
(0.029)\end{array}$ \\
\hline TOTAL ASSET & $\begin{array}{l}0.14 \\
(0.125)\end{array}$ & $\begin{array}{l}0.49^{*} \\
(0.254)\end{array}$ & $\begin{array}{l}0.74 * * * \\
(0.247)\end{array}$ & $\begin{array}{l}0.59 * * \\
(0.234)\end{array}$ & $\begin{array}{l}-0.67 * * \\
(0.287)\end{array}$ \\
\hline NPLOANS & $\begin{array}{l}0.25 \\
(0.179)\end{array}$ & $\begin{array}{l}0.15 \\
(0.335)\end{array}$ & $\begin{array}{l}0.55^{*} \\
(0.284)\end{array}$ & $\begin{array}{l}0.53^{*} \\
(0.3)\end{array}$ & $\begin{array}{l}0.86 * * \\
(0.351)\end{array}$ \\
\hline LOANS_GR & $\begin{array}{l}0.63 * * * \\
(0.03)\end{array}$ & $\begin{array}{l}0.47 * * * \\
(0.053)\end{array}$ & $\begin{array}{l}0.47 * * * \\
(0.049)\end{array}$ & $\begin{array}{l}0.5 * * * \\
(0.055)\end{array}$ & $\begin{array}{l}0.99 * * * \\
(0.055)\end{array}$ \\
\hline$G D P$ & $\begin{array}{l}-0.02 \\
(0.115)\end{array}$ & $\begin{array}{l}0.69 * * * \\
(0.21)\end{array}$ & $\begin{array}{l}0.97 * * * \\
(0.178)\end{array}$ & $\begin{array}{l}-0.04 \\
(0.193)\end{array}$ & $\begin{array}{l}-0.75 * * * \\
(0.238)\end{array}$ \\
\hline$S \& P I N D E X$ & $\begin{array}{l}2.27 * * * \\
(0.844)\end{array}$ & $\begin{array}{l}1.05 \\
(1.535)\end{array}$ & $\begin{array}{l}0.14 \\
(1.341)\end{array}$ & $\begin{array}{l}1.82 \\
(1.402)\end{array}$ & $\begin{array}{l}2.01 \\
(1.699)\end{array}$ \\
\hline Constant & $\begin{array}{l}7.2 * * * \\
(2.006)\end{array}$ & $\begin{array}{l}16.74 * * * \\
(4.239)\end{array}$ & $\begin{array}{l}7.09 * * \\
(3.531)\end{array}$ & $\begin{array}{l}6.35^{*} \\
(3.585)\end{array}$ & $\begin{array}{l}2.6 \\
(4.504)\end{array}$ \\
\hline Adj. R-square & $44.64 \%$ & $17.11 \%$ & $19.13 \%$ & $16.74 \%$ & $28.83 \%$ \\
\hline Observations & 937 & 897 & 906 & 875 & 919 \\
\hline
\end{tabular}

This table reports results of OLS regression of depositors' reaction to the announcement of EAs, by comparing the sample of sanctioned banks ( $\mathrm{Tg}$ ) with non-sanctioned banks $(\mathrm{Cg})$. The control group is estimated by applying PSM methodology and near neighbour matching estimation, as explained in Section 3.2. Depositors' reaction is measured as growth in total, saving, demand, time and core deposits. Variables are defined in Table 2, one quarter lag of independent variables is used and observations are on quarter-firm basis. Panel A investigates the effect of $T Y P E \_D$ on deposits, while Panel B introduces interaction terms between TYPE_D and event types (TYPE*C\&D and $\left.T Y P E^{*} C M P\right)$. Robust standard errors are reported in parenthesis under each coefficient. Source: Bloomberg database.

The $* * *, * *$ and $*$ denote significance at $1 \%, 5 \%$ or $10 \%$ level respectively. 
These results could be interpreted from two different points of view. On one hand, the absence of negative effects following EA announcements could highlight a need for increasing depositor's awareness. On the other hand, it shows supervisory action meets its purpose of reducing the risk of bank runs. Consequently, any policy initiative related to EA announcements should consider the balance between increasing depositors' awareness and avoiding bank runs.

\section{Conclusion}

This study investigates market movement and depositors' reaction following EA announcements on US banking institutions over the period 2004-2015. We complement previous literature by providing new empirical evidence across a range of EAs types and deposits. We employ event study and multivariate analyses on a wide dataset of US banks EAs to test the causal relationship of EAs on equity markets and depositors. We build a manually collected dataset of EA announcements by US supervisory authorities and validate the findings by identifying a sample of comparable non-sanctioned banks using PSM methodology. To the best of our knowledge, this is the first study that provides an in depth analysis of how key bank stakeholders, i.e. shareholders and depositors, react to US banks EAs.

Our results suggest equity market is able to discriminate EAs based on the severity of the sanction, by penalizing banks for more severe sanctions (C\&D), while reacting weakly for other sanctions (CMP and FA). A reduction in deposit growth is found for demand deposits and saving deposits following C\&D and CMP announcements, in line with previous literature expecting depositors to panic and withdraw funds from their sanctioned bank, while core depositors seem to reward sanctioned banks for a higher return following EA announcements. Following FA announcements, depositors tend to increase their deposits considering FA to be a less severe sanction and more of a corrective mechanism.

Equity market and depositors' reaction following EA announcements expand the existing knowledge on the consequences of banking supervision. Indeed, the existence of different market reactions based on the type of sanction highlights the need for banks to consequently adopt different behaviour, i.e. deciding to react or not following a sanction announcement, along with realigning their communication strategy based on the type of sanction to minimize reputational loss. The existence of different depositors' reaction based on the type of deposit (and sanction) suggests that banks should manage their relationship with depositors depending on the deposit (and sanction) type, i.e. considering demand depositors are willing to reduce their deposits following $C \& D$ announcements, while core depositors are willing to keep the funds for a higher return. From banking supervisors and policy makers' perspective, results from this study generate a better understanding of how supervisory enforcements affect shareholders and depositors. This could be relevant to deduce and guide further policy measures required when disclosing a formal EA and to enhance supervisory effectiveness. This would be important to help prevent panic among investors and depositors as well as other negative effects on banks and their stakeholders following an EA announcement.

Acknowledgements We would like to thank the Editor, the special issue co-Editor and the anonymous reviewers for their valuable comments and constructive suggestions. We are also grateful to the participants of the $6^{\text {th }}$ International Conference of the Financial Engineering and Banking Society (FEBS) held at the University of Malaga, Spain, in June 2016. 
Open Access This article is distributed under the terms of the Creative Commons Attribution 4.0 International License (http://creativecommons.org/licenses/by/4.0/), which permits unrestricted use, distribution, and reproduction in any medium, provided you give appropriate credit to the original author(s) and the source, provide a link to the Creative Commons license, and indicate if changes were made.

Publisher's Note Springer Nature remains neutral with regard to jurisdictional claims in published maps and institutional affiliations.

\section{References}

Ahlswede S, Schildbach J (2012) Poised for a comeback: Bank deposits. Deutsche Bank, DB Research: 1-16 Berger AN, Turk-Ariss R (2015) Do depositors discipline banks and did government actions during the recent crisis reduce this discipline? An international perspective. J Financ Serv Res 48(2):103-126

Boehmer E, Musumeci J, Poulsen AB (1991) Event-study methodology under conditions of event-induced variance. J Financ Econ 30:253-272

Brogi M (2011) Once bitten twice shy? A study on the effectiveness of administrative sanctions to discipline bank board members. Cell 39(335):5942276

Brous PA, Leggett K (1996) Wealth effects of enforcement actions against financially distressed banks. J Financ Res 19(4):561-577

Bruno B, Onali E, Schaeck K (2016) Market Reaction to Bank Liquidity Regulation. Journal of Financial and Quantitative Analysis (forthcoming)

Campbell JY, Lo AWC, MacKinlay AC (1997) The econometrics of financial markets, vol 2. Princeton University press, Princeton

Cerqueti R, Fiordelisi F, Rau PR (2016) Corporate culture and enforcement actions in banking. Conference paper 2016 at International Rome Conference on Money, Banking, and Finance XXV Edition

Chortareas GE, Girardone C, Ventouri A (2012) Bank supervision regulation and efficiency: evidence from the European Union. J Financ Stab 8(4):292-302

Corrado CJ, Zivney TL (1992) The specification and power of the sign test in event study hypothesis tests using daily stock returns. J Financ Quant Anal 27(3):465-478

Cowan AR (1992) Nonparametric event study tests. Rev Quant Finan Acc 2(4):343-358

Curry TJ, O'Keefe JP, Coburn J, Montgomery L (1999) Financially distressed banks: how effective are enforcement actions in the supervision process. FDIC Bank Rev 12:1-18

Danisewicz P, McGowan D, Onali E, Schaeck K (2014) The real effects of regulatory enforcement actions: Evidence from US counties. Available at SSRN 2407646

Davenport AM, McDill KM (2006) The depositor behind the discipline: a micro-level case study of Hamilton Bank. J Financ Serv Res 30(1):93-109

Davis EP, Obasi U (2009) The effectiveness of banking supervision. Working Paper No. 09-27

Delis MD, Staikouras PK (2011) Supervisory effectiveness and bank risk. MPRA paper no. 27242

Delis MD, Staikouras P, Tsoumas C (2013) Enforcement actions and bank behaviour. MPRA paper no.43557

Filotto U, Caratelli M, Ricci O (2014) Medium term effects of enforcement actions: evidence from the Italian banking system. EFMA Conference 2014

Finger H, Hesse H (2009) Lebanon-determinants of commercial bank deposits in a regional financial centre. IMF Working Papers:1-21

Gangl K, Torgler B, Kirchler E, Hofmann E (2014) Effects of supervision on tax compliance: evidence from a field experiment in Austria. Econ Lett 123(3):378-382

Gilbert RA, Vaughan MD (2001) Do depositors care about enforcement actions? J Econ Bus 53(2):283-311

Guo D, Jiang K (2013) Venture capital investment and the performance of entrepreneurial firms: evidence from China. J Corp Finan 22:375-395

Jordan JS, Peek J, Rosengren ES (1999) The impact of greater bank disclosure amidst a banking crisis. Federal Reserve Bank of Boston Vol.2

Kolari JW, Pynnonen S (2011) Nonparametric rank tests for event studies. J Empir Financ 18(5):953-971

MacKinlay AC (1997) Event studies in economics and finance. J Econ Lit 35(1):13-39

Park S, Peristiani S (1998) Market discipline by thrift depositors. Journal of Money, Credit and Banking: 347-364

Patell JM (1976) Corporate forecasts of earnings per share and stock price behaviour: Empirical test. Journal of Accounting Research: 246-276

Peek J, Rosengren ES (1995) Bank regulatory agreements in New England. New England Economic Review: $15-24$

Peek J, Rosengren ES (1996) Bank regulatory agreements and real estate lending. Real Estate Econ 24(1):55-73 
Ren J (2015) Market reaction to announcement of enforcement actions against related party transaction: Evidence from Chinese listed companies. Working Paper

Ricci O (2015) The impact of monetary policy announcements on the stock price of large European banks during the financial crisis. J Bank Financ 52:245-255

Rosenbaum PR, Rubin DB (1983) The central role of the propensity score in observational studies for causal effects. Biometrika 70(1):41-55

Semenova M (2007) How depositors discipline banks: the case of Russia. N.07-02e EERC Research Network, Russia and CIS

Srinivas V, Byler D, Wadhwani R, Ranjan A, Krishna V (2015) Enforcement actions in the banking industry: Trends and lessons learned. Deloitte Centre for Financial Services, Deloitte University Press

Vartanian TP, Schleusener MN (2012) Review of 2011 Bank enforcement actions and trends. BNA Insights 98(24):1053-1061

Zeidan MJ (2013) Effects of illegal behaviour on the financial performance of US banking institutions. J Bus Ethics 112(2):313-324

\section{Affiliations}

\section{John Pereira ${ }^{1} \cdot$ Irma Malafronte ${ }^{2} \cdot$ Ghulam Sorwar $^{3} \cdot$ Mohamed Nurullah $^{1}$}

Irma Malafronte

Irma.Malafronte@roehampton.ac.uk

Ghulam Sorwar

G.Sorwar@Salford.ac.uk

Mohamed Nurullah

M.Nurullah@kingston.ac.uk

1 Kingston Business School, Kingston University, Kingston Upon Thames, Surrey KT2 7LB, UK

2 Roehampton Business School, University of Roehampton, 80 Roehampton Lane, London SW15 5SL, UK

3 Salford Business School, University of Salford, Maxwell Building, The Crescent, Salford M5 4WT, UK 